\title{
GLUT1 deficiency
}

\section{Retinal detrimental effects of gliovascular modulation}

Matt Henry, MD, John Kitchens, MD, Juan M. Pascual, MD, PhD, and Ramiro S. Maldonado, MD

Neurol Genet 2020;6:e472. doi:10.1212/NXG.0000000000000472

\author{
Correspondence \\ Dr. Maldonado \\ ramiro.maldonado@uky.edu
}

Most patients with glucose transporter type 1 (GLUT1) deficiency syndrome (G1D) experience anticonvulsant-refractory epilepsy and abnormal cognitive and motor development. ${ }^{1}$ Ninety percent of patients with G1D harbor a causative loss-of-function mutation in the SLC2A1 gene; in the others, brain fluorodeoxyglucose (FDG) PET can confirm the diagnosis.

G1D investigation has centered on the cerebral aspects of the disease, but extracerebral manifestations are plausible. ${ }^{1}$ The eye is a likely substrate: retinal GLUT1 sustains ocular glucose transport based on its expression in Müller, vascular endothelial, and pigmentary epithelial cells. Notably, GLUT1 is a target for diabetic retinopathy drugs. ${ }^{2,3}$ We describe retinal abnormalities in a patient with G1D in the broader context of the plausible mechanisms and consequences of retinal GLUT1 loss of function or therapeutic inhibition.

\section{Case report}

A 20-year-old woman with the common epileptic form of G1D reported subnormal visual acuity uncorrectable with glasses and harbored a de novo pathogenic SLC2A1 variant (c.1454C >T; P485L). ${ }^{1,4}$ The mutation introduced a dileucine motif in GLUT1 associated with clathrin recruitment and excessive internalization of cell membrane GLUT1. ${ }^{5}$

Her visual acuity was 20/40 (OD) and 20/30 (OS) with no other obvious ocular abnormalities. Optical coherence tomography (OCT) revealed retinal thinning in the posterior pole respecting the fovea (figure $1, \mathrm{~A}$ and $\mathrm{B}$ ) and absence of the interdigitation band peripherally with moderate photoreceptor layer thinning (figure 1, C and D). Swept source OCT demonstrated significant choroidal thickening (571 and $495 \mu \mathrm{m}$ in the OD and OS, respectively; normal for age: $\sim 330-400 \mu \mathrm{m}$ ). Retinal fundus autofluorescence (FAF) demonstrated hyperautofluorescence outside the fovea and an unusual hyperautofluorescence in the central fovea (figure 1, E and F). OCT-angiography (OCTA) showed a paucity of perimacular vessels (figure $1, \mathrm{G}$ and $\mathrm{H}$ ).

There were functional correlates to these findings, including multiple D-15 Farnsworth color testing defects in the protan axis bilaterally and suppressed cone flicker amplitudes with normal rod system electroretinography (ERG) responses (figure e-1, links.lww.com/NXG/A276). Repeat testing over 1 year was invariant.

\section{Discussion}

Our patient with G1D exhibited structural and functional retinal dysfunction. The retinal changes were congruent across all imaging modalities: the retinal thinning noted on macular color thickness maps correlated with the hyperautofluorescence on FAF and with the area of reduced 
Figure 1 Retinal multimodal imaging in a patient with GLUT1 deficiency
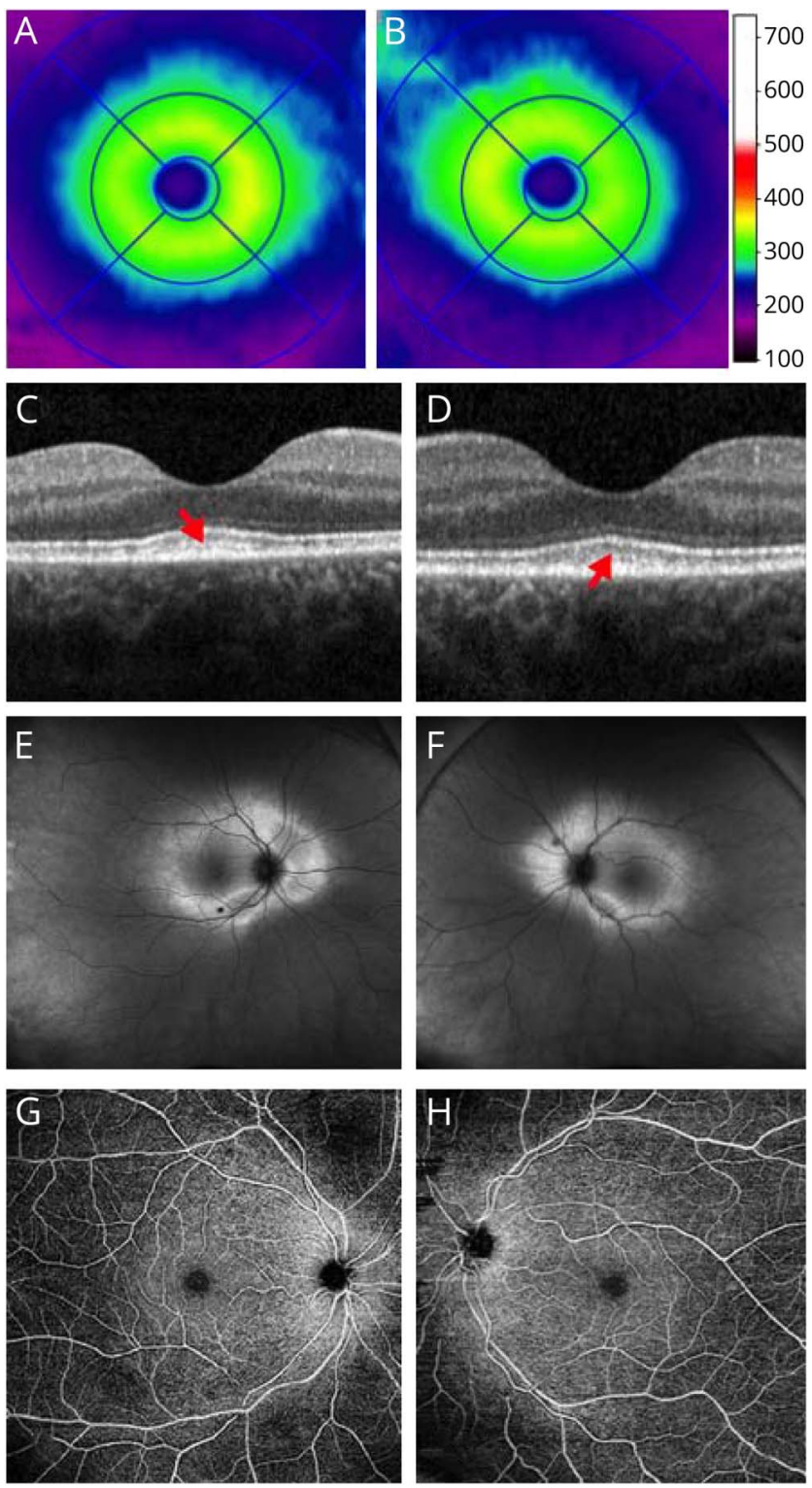

(A and B) Optical coherence tomography (OCT) total macular color thicknessmaps (in microns) showing marked retinal thinning (blue-purple area) outside the fovea in the right and left eyes, respectively. (C and D) OCT b-scans at the foveal centers demonstrate thickened retinal pigment epithelial layer interdigitation bands (red arrows) only at the foveal centers; the bands disappear in the periphery of the scans. ( $E$ and F) Wide-field fundus autofluorescence (FAF) images of the right and left eye, respectively, showing increased FAF in the perifoveal area corresponding to the area of retinal thinning depicted in (A and B). Note that the fovea demonstrates subtle but abnormal hyperautofluorescence centrally; this area normally shows hypoautofluorescence because of macular pigment AF blockage. ( $G$ and $H$ ) OCT angiography (OCTA) of the superficial capillary plexus demonstrates decreased perimacular vessel density. (A-F) See figure e-2 (links.lww.com/NXG/ A276) for comparison of all images to those of a normal subject.

vessel density on OCTA. Together with the thickened choroid and decreased cone flicker, the simplest interpretation of our findings is early onset photoreceptor degeneration.

In the retina, Glut1-mediated transport occurs across capillary endothelial cells of the inner blood-retinal barrier and the retinal pigment epithelium (RPE). This implies that our patient's de novo somatic (and therefore uniformly vascular and glial because there is no reason to suspect mosaicism) mutation exerts secondary consequences on neurons (which are largely devoid of GLUT1). This likely stems from reduced glucose (or another mediator) flux across retinal cell types.

Modest GLUT1 expression changes are functionally relevant: increased renal GLUT1 has deleterious consequences in diabetic nephropathy. ${ }^{6}$ Conversely, GLUT1 small interfering RNAs (siRNAs) reduce retinal glucose and ameliorate diabetic retinopathy, which is accompanied by reduced ERG signal amplitude and outer nuclear layer thinning. ${ }^{3}$ This is analogous to our patient's diminished cone flicker amplitude and retinal thickness. Furthermore, diabetic mice exhibit increased RPE GLUT1 expression after prolonged exposure to hyperglycemia and hypoxia. The resulting elevated RPE glucose can be associated with impaired pigment epitheliumderived (PEDF) secretion, leading to imbalanced vascular endothelial growth factor (VEGF)/PEDF and stimulated neovascularization. ${ }^{3}$ Our patient exhibited reduced capillary density, which may reflect altered VEGF/PEDF release as in diabetic retinopathy.

Some diabetic retinopathy therapies target GLUT1, including angiotensin-converting enzyme inhibitors such as captopril. This occurs, in part, via decreased retinal glucose after the reduction of GLUT1-mediated glucose transport (despite unaltered GLUT1 expression). Intraocular siRNA diminishes GLUT1 expression in the inner blood-retinal barrier of streptozotocin-diabetic mice and decreases retinal glucose. ${ }^{3}$ Last, GLUT1 inhibition by forskolin or genistein in diabetic mice leads to similar results. In all these contexts, retinal glucose decreases after treatment, suggesting that GLUT1 inhibition can counteract the end result of multifactorial diabetic retinopathy.

However, GLUT1 inhibition may be detrimental to photoreceptor and $\mathrm{RPE}$ cells. In mice, reduction of $\mathrm{RPE}$ glucose via GLUT1 knockout results in outer segment shortening, photoreceptor cell death, and Müller cell activation. This underscores the importance of near-constant GLUT1 activity in the retina. ${ }^{7}$ Our findings suggest that these experimental observations are likely relevant in humans, suggesting that therapeutic GLUT1 inhibition may result in undesired effects.

\section{Conclusions}

Our case demonstrates the contribution of nonneural GLUT1 to retinal cell (including photoreceptor) activity and vision. Although diabetic retinopathy therapies that inhibit GLUT1 are plausible, this inhibition may be detrimental. This case also illustrates the value of retinal assessment in G1D and in those receiving GLUT1-related diabetes therapies. 


\section{Acknowledgment}

The authors acknowledge the collaboration of the patient described and her legally consenting family. The support of the Glucose Transporter Type 1 Deficiency Foundation and of the NIH (grant NS077015 to J.M.P.) is also acknowledged.

\section{Study funding}

Supported by Glut1 Deficiency Foundation.

\section{Disclosure}

The authors report no disclosures relevant to the manuscript. Go to Neurology.org/NG for full disclosures.

\section{Publication history}

Received by Neurology: Genetics January 16, 2020. Accepted in final form June 1, 2020.

\section{Appendix Authors}

\begin{tabular}{lll}
\hline Name & Location & Contribution \\
\hline $\begin{array}{l}\text { Matt Henry, } \\
\text { MD }\end{array}$ & $\begin{array}{l}\text { University of } \\
\text { Kentucky, } \\
\text { Lexington }\end{array}$ & $\begin{array}{l}\text { Data acquisition and drafted the } \\
\text { manuscript for intellectual content }\end{array}$ \\
\hline $\begin{array}{l}\text { John } \\
\text { Kitchens, } \\
\text { MD }\end{array}$ & $\begin{array}{l}\text { University of } \\
\text { Kentucky, } \\
\text { Lexington }\end{array}$ & $\begin{array}{l}\text { Design and conceptualization, data } \\
\text { acquisition, critical review, and } \\
\text { drafting of the manuscript }\end{array}$ \\
\hline
\end{tabular}

Appendix (continued)

\begin{tabular}{lll}
\hline Name & Location & Contribution \\
\hline $\begin{array}{l}\text { Juan M. } \\
\text { Pascual, } \\
\text { MD, PhD }\end{array}$ & $\begin{array}{l}\text { University of Texas } \\
\text { Southwestern, } \\
\text { Dallas }\end{array}$ & $\begin{array}{l}\text { Data acquisition, interpreted the } \\
\text { data, and revised the manuscript } \\
\text { for intellectual content }\end{array}$ \\
\hline $\begin{array}{l}\text { Ramiro S. } \\
\text { Maldonado, } \\
\text { MD }\end{array}$ & $\begin{array}{l}\text { University of } \\
\text { Kentucky, }\end{array}$ & $\begin{array}{l}\text { Design and conceptualization, } \\
\text { data acquisition, critical review, } \\
\text { and drafting of the } \\
\text { manuscript }\end{array}$ \\
\hline
\end{tabular}

\section{References}

1. Pascual JM, Ronen GM. Glucose transporter type I deficiency (G1D) at 25 (1990-2015): presumptions, facts, and the lives of persons with this rare disease. Pediatr Neurol 2015;53:379-393.

2. Calado SM, Alves LS, Simao S, Silva GA. GLUT1 activity contributes to the impairment of PEDF secretion by the RPE. Mol Vis 2016;22:761-770.

3. You ZP, Zhang YL, Shi K, et al. Suppression of diabetic retinopathy with GLUT1 siRNA. Sci Rep 2017;7:7437.

4. Slaughter L, Vartzelis G, Arthur T. New GLUT-1 mutation in a child with treatmentresistant epilepsy. Epilepsy Res 2009;84:254-256.

5. Meyer K, Kirchner M, Uyar B, et al. Mutations in disordered regions can cause disease by creating dileucine motifs. Cell 2018;175:239-253.e17.

6. Heilig CW, Liu Y, England RL, et al. D-glucose stimulates mesangial cell GLUT1 expression and basal and IGF-I-sensitive glucose uptake in rat mesangial cells: implications for diabetic nephropathy. Diabetes 1997;46: 1030-1039.

7. Swarup A, Samuels IS, Bell BA, et al. Modulating GLUT1 expression in retinal pigment epithelium decreases glucose levels in the retina: impact on photoreceptors and Muller glial cells. Am J Physiol Cell Physiol 2019;316: C121-C133. 


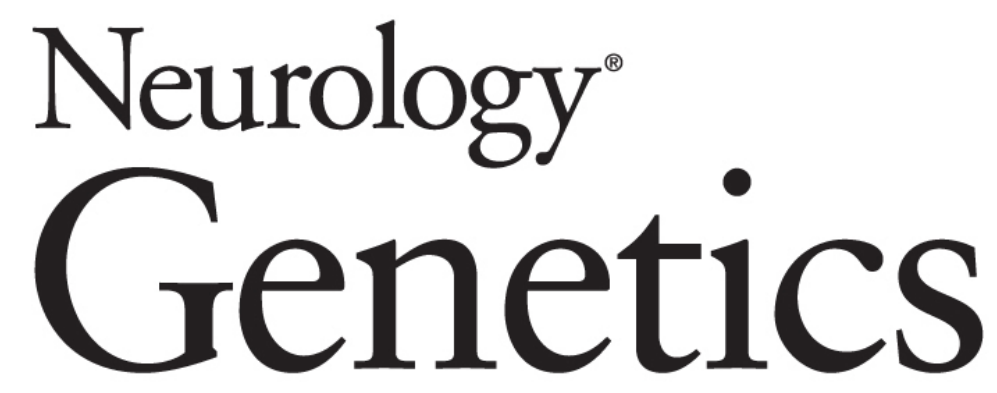

\section{GLUT1 deficiency: Retinal detrimental effects of gliovascular modulation \\ Matt Henry, John Kitchens, Juan M. Pascual, et al. \\ Neurol Genet 2020;6; \\ DOI 10.1212/NXG.0000000000000472}

This information is current as of June 25, 2020

\section{Updated Information \& Services}

References

Permissions \& Licensing

Reprints including high resolution figures, can be found at: http://ng.neurology.org/content/6/4/e472.full.html

This article cites 7 articles, 1 of which you can access for free at: http://ng.neurology.org/content/6/4/e472.full.html\#\#ref-list-1

Information about reproducing this article in parts (figures,tables) or in its entirety can be found online at:

http://ng.neurology.org/misc/about.xhtml\#permissions

Information about ordering reprints can be found online: http://ng.neurology.org/misc/addir.xhtml\#reprintsus

Neurol Genet is an official journal of the American Academy of Neurology. Published since April 2015, it is an open-access, online-only, continuous publication journal. Copyright Copyright $\odot 2020$ The Author(s). Published by Wolters Kluwer Health, Inc. on behalf of the American Academy of Neurology.. All rights reserved. Online ISSN: 2376-7839.

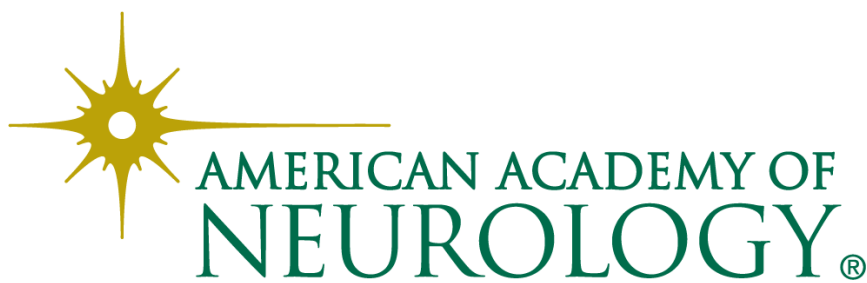

